\title{
El ensayo visual: una tipología emergente de artículos de
}

investigación-creación

\section{Pedro Pablo Gómez}

Editor

Universidad Distrital Francisco José de Caldas

ppgmez@udistrital.edu.co

Cómo citar este artículo: Gómez, Pedro Pablo. (2020). El Ensayo Visual: una tipología emergente de artículos de investigación-creación. Calle14: revista de investigación en el campo del arte, 15(28), pp. 216-221.

https://doi.org/10.14483/21450706.16901 

La vida de las revistas se puede medir en las dinámicas de sus secciones. Y Calle14 no ha sido la excepción en este aspecto. A lo largo de 28 números realizados desde el año 2007 hemos visto cómo la sección central se ha convertido en la principal de la revista, abarcando artículos que dan cuenta de la investigación y la creación en estas modalidades: artículo de investigación artística, científica y tecnológica, artículo de reflexión y artículo de revisión. Pero la denominación de artículo de investigación artística es una inserción nuestra, con el propósito editorial de tener una revista "científica" indexable e indexada desde el campo de las artes, que al mismo tiempo no claudique a las lógicas, formatos y jerarquías de las ciencias duras. Tarea ardua y compleja, que al menos, pensamos, nos permite interpelar la realidad desde las mencionadas lógicas y jerarquías que surgen en las ciencias naturales, pasan a las ciencias sociales, las ciencias humanas y terminan inscribiéndose en las artes.

Desde nuestra perspectiva, la categoría investigación-creación, conceptualizada e implementada de manera heterogénea en facultades y programas de arte en varias partes del mundo, hace posible, entre otras cosas, el reconocimiento de la producción de conocimientos más allá de las ciencias, específicamente en las artes y los movimientos sociales y comunitarios. Y en ese espacio de sentido de la investigación creación, sería posible des-jerarquizar la tipología de los artículos de investigación, reflexión y revisión y también la emergencia de otros tipos de artículos que se puedan ubicar en la sección central de las revistas y no, como hasta ahora, en las secciones secundarias. Este es el caso del ensayo visual que desde hace un tiempo venimos proponiendo en Calle14 y en la Revista Estudios Artísticos.

Ahora bien, estoy seguro de que hay una amplia producción de ensayos visuales, la cual desafortunadamente no se nombra como tal. Por tal razón, lo que es un ensayo visual no puede ser definido a priori como una categoría normativa de las prácticas que dan lugar a su elaboración y posterior publicación, recepción y apropiación social. Lo que hay es una serie heterogénea de posibilidades para la configuración de un ensayo de ese tipo, que cuando menos es una forma distinta de plantear el lugar de las imágenes en la producción de conocimientos en relación con el texto escrito, la narración oral, la percepción y la compresión del mundo.

En el ensayo visual las imágenes no se conforman con ser ilustraciones de los textos o transiciones visuales, de reposo, en medio de la densidad analítica y la interpretación de datos. Tampoco se pretende que los textos sean reducidos a nada más que pie de imágenes; se trata, en cambio, de tejer el sentido de maneras no necesariamente lineales entre imágenes y textos, para localizar el pensamiento en contextos precisos desde donde se pueda senti-pensar y dialogar de un modo más horizontal. Así, la potencia del ensayo visual consiste, a mi modo de ver, en re-actualizar la pregunta por las relaciones entre los distintos modos de producción e interpretación de los signos, 
sus soportes y medios. ¿Qué significa pensar con, desde y a través de las imágenes? Esa es otra cuestión importante que podemos abordar con base en el ensayo visual, además de cuáles son las relaciones y diferencias entre las imágenes del pensamiento que se construyen desde las ciencias, las artes y el pensamiento popular.

Obviamente, no podemos dejar de ser conscientes de la hegemonía de la imagen en la cultura occidental, centrada en la particular imagen físico-matemática del mundo construida por la ciencia como dispositivo de representación, además de los regímenes racializados derivados de esta. Estos regímenes encuentran su soporte en la cultura letrada, la cultura visual, así como en los medios masivos de comunicación, el cine, la fotografía y demás artes en las que se re-presenta al otro y lo otro siempre como inferior. Ni apología ni estigmatización de la imagen, ni iconolatría ni iconoclastia radicales, se trata aquí de repensar las relaciones entre modos de pensar mediadas por lenguajes alfabéticos o lenguajes icónicos y prácticas de oralidad. A continuación, recopilamos varios ejemplos de ensayo visual que, aunque no necesariamente denominados como tal, hemos publicado en nuestras revistas:

Escritores, fotografías y retratos, una entrevista a Abdú Eljaiek, por Santiago Rueda Fajardo (2016), es un ensayo visual en el que se hace un recorrido por la personalidad del fotógrafo y las circunstancias que envuelven sus retratos de personajes de la cultura colombiana como Eduardo Caballero y León de Greiff.

Sobre la serie "tiempos revueltos", de Marcos Roda Fornaguera (2015), pretende sacar de contexto momentos y personajes de la historia para situarlos en tiempos y situaciones que no corresponden a los suyos. La idea de que la historia, como nos la han enseñado, con sus inamovibles pedestales y sus héroes de mármol, es demasiado cómoda, impulsa al autor a jugar, a irrespetar roles.

En el planeta Ingmar Bergman, de Sandro Romero-Rey (2018) con imágenes de León García Jordán, presenta un viaje al universo creativo de uno de los realizadores más importantes de la historia por su representación de los asuntos radicales de la vida y la muerte.

El arte de la memoria en la arquitectura. Rogelio Salmona y sus memorias de África, de la autora Sasha Londoño (2018), plantea que los recuerdos y reminiscencias de la experiencia del arquitecto en sus viajes a África quizá hayan quedado guardados en su memoria para luego poder ser encontrados a través de fragmentos por quienes visitan, habitan o recorren su propia arquitectura.

De la serie El jardín perdido, de Hanna Ramone (2018), construye un conjunto de imágenes basadas en la reflexión acerca del problema social del feminicidio, que 
afecta a mujeres de todas las edades y nacionalidades, y la mayoría de las veces queda en la impunidad.

El genio secreto del catalejo (Kikkertens Hemmelighedsfulde Aand), de Sandra Rengifo y Fernando Escobar Neira (2018), es otro ensayo que se aleja en su perspectiva de discursos propios de la historia del arte y de la estética, e instala preguntas más cercanas a campos de conocimiento como la geografía cultural, los estudios del paisaje y los estudios visuales. El objetivo principal de este trabajo es describir la relación y tensiones que mantiene el proyecto artístico con respecto a espacialidades, objetos, lugares y paisajes.

Poéticas blandas: ondulantes, sinuosas y distorsiones (2006-2017), de John Castles (2018), ofrece una muestra significativa del trabajo plástico y visual realizado por el artista en la última década. Las imágenes de las obras son acompañadas por breves pronunciamientos de especialistas, teóricos y curadores latinoamericanos. De esta manera, se puede ver la relación de complementariedad que se establece entre la sensibilidad y el pensamiento en la poesía-plástica que atraviesa su ya extensa obra.

Sísifos... una montaña en las espaldas, anhelos de una chispa dorada, de Daniel Ospina Moreno (2019), es un relato visual basado en una experiencia que busca comprender desde adentro las dinámicas del extractivismo y sus impactos en la naturaleza y la sociedad. El autor habitó por dos meses en un contexto de extracción ilegal de oro, y su experiencia se conecta con la pregunta que indaga por las expresiones y huellas del diálogo hombre-naturaleza en Colombia, lo que lo lleva a apropiarse la geografía desde la vivencia.

City of Refuge (Ciudad de refugio) de los autores Sandra Rengifo y Kostas Tsanakas es un ensayo en el que los textos aparecen como un acompañamiento o susurro de lo que evocan cada una de las imágenes y su conjunto. La perspectiva de los autores se instala en una escritura experimental sobre los recorridos, lo sugerido por las imágenes, el ver el mundo a través de los ojos de Tsanakas y el acto de nomadismo presente en los fotógrafos del andar.

Muy probablemente, el ensayo visual seguirá apareciendo en las publicaciones académicas clasificado bajo la rúbrica de algún otro tipo de artículo. Nuestra aspiración es trabajar para posicionar el ensayo visual como una modalidad de artículo con igual reconocimiento que los de investigación, reflexión y revisión. Mientras tanto, vamos avanzando en la tarea de vislumbrar la potencia y consistencia del ensayo visual como soporte del pensamiento sensible y la imaginación creadora en y más allá del campo de las artes. 
Referencias

Castles, J. (2018). Poéticas blandas: ondulantes, sinuosas y distorsiones (20062017). Calle 14 Revista De investigación En El Campo Del Arte, 13(23), 16-37. https://doi.org/10.14483/21450706.12986

Londoño Venegas, S. (2018). El arte de la memoria en la arquitectura. Rogelio Salmona y sus memorias de África: concierto de recuerdos, experiencias y composición. Calle 14 Revista De investigación En El Campo Del Arte, 13(23), 74-100.

https://doi.org/10.14483/21450706.12990

Mignolo, W. (2019). Reconstitución epistémica/estética: la aesthesis decolonial una década después. Calle 14 Revista De investigación En El Campo Del Arte, 14(25), 14-33. https://doi.org/10.14483/21450706.14132

Ospina Moreno, D. (2019). Sísifos... una montaña en las espaldas, anhelos de una chispa dorada. Calle 14 Revista De investigación En El Campo Del Arte, 14(25), 34-57. https://doi.org/10.14483/21450706.14074

Ramone, H. (2018). De la serie El jardín perdido. Calle14 revista de investigación en el campo del arte, 13(24), 288-303. https://doi.org/10.14483/21450706.13526

Rengifo, S., \& Tsanakas, K. (2020). City of refuge (Ciudad de refugio). Estudios Artísticos, 6(8), 20-41. https://doi.org/10.14483/25009311.15689

Rengifo, S., \& Escobar Neira, F. (2018). El genio secreto del catalejo (Kikkertens Hemmelighedsfulde Aand). Calle 14 Revista De investigación En El Campo Del Arte, 13(24), 254-287. https://doi.org/10.14483/21450706.13525

Rey, S. R. (2019). En el planeta Ingmar Bergman. Estudios Artísticos, 5(6), 30-43. https://doi.org/10.14483/25009311.14098

Roda Fornaguera, M. (2015). Sobre la serie "tiempos revueltos". Estudios Artísticos, 1(1), 156-173. https://doi.org/10.14483/25009311.10253

Rueda Fajardo, S., \& Eljaiek, A. (2016). Escritores, fotografías y retratos; una entrevista a Abdú Eljaiek (3 de febrero 2005). Estudios Artísticos, 2(2), 132-155. https://doi.org/10.14483/25009311.11532 